\title{
A perspective on marriages and civil unions in South Africa (Part one)
}

NGTT DEEL 55, NR 3 \& 4, 2014

\section{Coertzen, Pieter}

Stellenbosch University

\begin{abstract}
The aim of this article to take a look at and assess the current situation in South Africa regarding marriages and civil unions from a Christian theological and historical perspective. The question to be answered is: Where do churches stand with regard to marriages and civil unions? Are they merely to accept the way current laws on face value arguing that the state has the right to make laws and to enforce them and churches just have to obey the laws of the state or does the human rights of freedom of religion and freedom of association as part of state legislation give churches the options to exercise their faith identity in the matters of marriage and civil unions?
\end{abstract}

\section{KEYWORDS}

Marriage, Civil Unions, Christian perspective, Freedom of Religion, Freedom of Association

\section{TREFWOORDE}

Huwelik, burgerlike vakbonde, Christelike perspektief, Godsdiensvryheid, Vryheid van assosiasie

\section{CONTACT DETAILS}

Prof Pieter Coertzen

Unit for the Study of Law and Religion

Beyers Naudé Center for Public Theology

Faculty of Theology, Stellenbosch University

Privaatsak X1, Matieland, Suid-Afrika, 7602

pc@sun.ac.za 


\section{PART 1: MARRIAGE}

\subsection{Introduction}

Relationships like marriage, civil unions and partnerships between people play a very important role in everyday life. It is important for the wellbeing of a society to set the boundaries in which the relationship between couples may or may not function. Laws are made to protect people in these relationships and to bring about assurances of care and safety for husbands, wives, partners and children who are part of or the result of the relationships between adults. The mentioned relationships are also very important for all religions. Religions often have very deep convictions about these matters. For some religions these relationships are important as part of their religious convictions and religious history and traditions; other religions see marriage as a sacrament and have strict rules and even religious courts to guard over them. Some religions allow polygamy while other religions have strict rules to keep marriage monogamous. In our day marriages are threatened by an increasingly high rate of divorce and also from people who just ignore and disregard marriage as an institution apart from many other societal influences that put marriages under pressure.

The aim of this article to take a look at and assess the current situation in South Africa regarding marriages and civil unions from a Christian theological and historical perspective. The question to be answered is: where do churches stand with regard to marriages and civil unions? Are they merely to accept the way current laws on face value arguing that the state has the right to make laws and to enforce them and churches just have to obey the laws of the state or does the human rights of freedom of religion and freedom of association as part of state legislation give churches the options to exercise their faith identity in the matters of marriage and civil unions.

\subsection{Marriage in the relationship between church and state}

An historical overview of the relationship between church and state with regard to marriage can be helpful to answer the above questions.

During the times of the Old Testament and for many centuries until this day marriage for Old Testament believers and Christian churches were not merely a civil contract between two people it was much more. For Old Testament believers and Christian churches marriage was instituted by God and in later times the marriage ceremony in a church was not merely a religious dedication or a prayer for the blessing of God, it was and is essentially a ministering of the Word of God, an intricate part of the 
covenant of grace. The apostle Paul describes the marriage between a man and a wife as a mystery and a mirror of the relationship between Christ and His church.

For this reason Christian churches have a great share and responsibility and also certain rights with regard to the marriage of its members. The church for instance has the right to determine where the marriage of its members be solemnized, who is allowed to have their marriage solemnized as a Christian marriage, who is allowed to solemnize a marriage and what are the general rules of the church that must be complied with. ${ }^{1}$

However not only the church but also the state authorities have a right, as well as a share and a responsibility towards the marriage of citizens. These rights and responsibilities of the state authorities developed gradually from a situation where mainly the husband and wife and their respective families were involved. When the Early Church came into being it accentuated the consent of the two parties and the engagement, which the church blessed. The marriage as such took place in the house of the bride's father while later in the evening the bride was received in the house of the bridegroom. For the rest the church complied with the rules of Roman law. This gradually lead to a situation where the church came more and more under the authority of emperors and their laws, also the marriage laws, that they made. This system of the relationship between church and state became to be known as system of Caesero-Papism, also called Constantianism or Erastianism by some.

After $313 \mathrm{AD}$ when the Christian church was first recognised by the state authorities in the Edict of Milan as a tolerated religion of equal status with other religions, Christian marriages were still conducted in the houses of Christians but was solemnized in the church and sealed through the Holy Communion. It was only at the synod of Laodicea (363 AD) that the solemnisation of marriages in houses was no longer allowed. In 380 Emperor Theodosius proclaimed the Christian Church to be the State Church of the Empire. This development brought about fundamental changes also with regard to Christian marriages. "Being a Christian became the norm, and more or less identical with being a citizen. The "Church" and "the people" became the same thing."

This situation again changed fundamentally in the eleventh century with the socalled Papal Revolution. As Pope Gregory VII, Hildebrand "proclaimed the legal supremacy of the pope over all Christians and the legal supremacy of the clergy,

1 Bouwman, H. 1970, Gereformeerd Kerkrecht. Het Recht der Kerken in de Practijk deel II. J.H. Kok N.V., Kampen, tweede Onveranderde Druk,p 519.

2 Blei, Karel, 2002, Freedom of Religion and Belief: Europe's Story. Royal Van Gorcum, Assen, The Netherlands. p 25. 
under the pope, over all secular authorities." He also "proclaimed that all bishops were to be appointed by the pope only and were to subordinate ultimately to him and not to secular authority." Once again this development had a tremendous influence on marriage. Marriage now became a sacrament, over which the church ruled. The pope and in him the church now had absolute power in a way which can be called theocratic - religion or a church dictates the rules for individuals and society. It was this absolute power of the pope that lead to the Reformation of the sixteenth century.

The Calvinistic Reformation reacted to the theocratic rule of the Roman Catholic Church by proclaiming that Jesus Christ was the only Head of the Church, ${ }^{3}$ a position that He did not share with the pope, and that He ruled His Church through His Word and the Spiritual order set out in his Word. ${ }^{4}$ However with regard to the relationship between the church and the state the Reformation did not bring forward new insights. By proclaiming in article 36 of the Belgic Confession that it was the task of the authorities not only to care and watch over the public domain but to also uphold the sacred ministry, "with a view to removing and destroying all idolatry and false worship of the Antichrist; to promote the kingdom of Jesus Christ; and to furthering the preaching of the gospel everywhere, to the end that God may be honoured and served by everyone, as he requires in his Word." 5 This was in fact a return to the Caesaro-Papism of the early church of the fourth century. Only now, in some countries as for example, in England, after Henry VIII became the head of the Anglican Church, and in the Netherlands and later on in its colonies like South Africa, the expression "Being a Christian became the norm, and more or less identical with being a citizen"6 was traded for: "being a Reformed or an Anglican Christian became the norm, and more or less identical with being a citizen." While the reformation brought about wonderful true insights regarding the salvation of man and the church, it was not the same for the relationship between church and state.

3 The Belgic Confession,art 31, in: This We Believe, Thus We Confess. The Doctrinal Standards of the Dutch Reformed Church. Published by: DRC Synod of Central Africa, Harare, Zimbabwe, $2^{\text {nd }}$ Print, Cava, October 2000.

4 The Belgic Confession,art 30, in: This We Believe, Thus We Confess. The Doctrinal Standards of the Dutch Reformed Church. Published by: DRC Synod of Central Africa, Harare, Zimbabwe, $2^{\text {nd }}$ Print, Cava, October 2000.

5 The Belgic Confession,art 36, in: This We Believe, Thus We Confess. The Doctrinal Standards of the Dutch Reformed Church. Published by: DRC Synod of Central Africa, Harare, Zimbabwe, $2^{\text {nd }}$ Print, Cava, October 2000.

6 Blei, Karel, 2002, Freedom of Religion and Belief: Europe's Story. Royal Van Gorcum, Assen, The Netherlands. p 25. 
The Netherlands had been under the Spanish imperial rule until about the middle of the sixteenth century. This meant that the country was also subject to the canon law of marriage as administered by the Bishop of Utrecht. By 1581 the seven northern provinces, which forms the Netherlands of today, turned to the reformed cause. In terms of article 36 of the Belgic Confession this meant that civil authorities assumed jurisdiction over a host of matters that were previously governed by church courts including marriage. "New legislation and learned law on marriage drew upon a variety of Catholic canon law and Genevan civil law prototypes." Where Calvin had insisted that marriage certificates be issued by the magistrates but that the wedding itself is celebrated in a church, "Dutch Calvinists accorded equal authority to both church and state to certify and solemnize the marriage, leaving the choice of forum to the parties." ${ }^{\text {On }} 1$ April 1580 the Political Ordinance of the States of Holland prescribed on pain of nullity, the publication of banns and the solemnization marriage by a minister of the Church or a magistrate in the presence of no fewer than two witnesses. ${ }^{9}$ Here again we see the co-operation of Church and State and how the state in fact upheld the Reformed Christian religion.

In article 70 of the Church Order of Dordt (1618-1619) the Reformed Churches of the Netherlands declared that with regard to marriages there were different uses in sway in the Netherlands and until it was possible to get conformity the churches could stay with the use which they were following until such time that the high authorities, on request of the churches, had made a general ordinance with the advice of the churches. ${ }^{10}$ It is apparent that both the church and the state had a role to play with regard to marriage. The churches were willing to leave the drafting of marriage ordinances in the hands of the civil authorities on condition that they had the right to give advice. In reality it developed into a situation that the civil authorities made the marriage laws and the churches submitted to it. ${ }^{11}$

In 1652 the Dutch East Indian Company, under a Charter of the Estates General in the Netherlands, started a refreshment post at the Cape of Good Hope. Under

7 Witte, John Jr, 1997. From Sacrament to Contract. Marrige, Religion, and Law in the Western Tradition. Westminster John Knox Press, Louisville, Kentucky. p 127-128.j

8 Witte, John Jr, 1997. From Sacrament to Contract. Marrige, Religion, and Law in the Western Tradition. Westminster John Knox Press, Louisville, Kentucky. p 129

9 Sinclair, June D, 1996. The Law of Marriage Vol 1. Juta \& Co, LTD. p 191.

10 Kerken-Orde van De Synode Nationaal 1618 en 1619, artikel 70. In: Pont, A.D., 1981. Die historiese agtergronde van ons Kerklike Reg, Deel 1. HAUM, Pretoria Kaapstad.

11 Nauta, D.,1971. Verklaring van de Kerkorde van de Gereformeerde Kerken in Nederland. J.H. Kok, Kampen. P 303. 
the Charter the Company held the power of government, also with regard to the Reformed religion at the Cape. At that time the Reformed religion was the only religion that was allowed at the Cape. The rules and uses regarding marriage were aligned to the legal and moral codes of the Netherlands.

In 1801 a new political order under Commissioner De Mist took shape in the Cape, the so-called Batavian rule under the Batavian Republic in the Netherlands. On 20 September 1804 a new Marriage Ordinance was proclaimed. De Mist determined in the Ordinance that marriage was merely a civil matter and that a minister or the church need not be involved in the concluding of a marriage. But soon after the British took over the Cape in 1806, Governor Sir David Baird issued a Proclamation on 26 April 1806 in which he revoked the Church Ordinance of De Mist and proclaimed that since in all civilised countries, where the Christian Religion was confessed and kept, the marriage ceremony was rightly seen as a holy institution which relates to the ground principles of the (Christian) religion and not as the Ordinance of De Mist would suggest as a mere civil covenant. He therefor proclaimed that an ordained minister belonging to the colony must conduct in future all marriage ceremonies. ${ }^{12}$

What happened in reality was that the state retained its power of authority over the Church in a caesero-papist or erastian way. This comes very clearly to the fore in Ordinance no 7 of 1843 through which the church was obliged to send its own decisions to the authorities "to receive the sanction of secular authority. ${ }^{13}$

This situation of co-operation between church and state but at the same time the state keeping its authority over the church continued for many decades up until 1996.

In October 1962 the five Dutch Reformed Churches from the provinces of the Cape, Natal, the Orange Free State, Transvaal and South West Africa met in Cape Town to constitute the new General Synod of the Dutch Reformed Church. ${ }^{14}$ At this synod

12 Baird, David, Gen Majoor, Proclamatie 26 April 1806, Kaapsche Stads Courant, Deel 1, No 15, 26 April 1806. In:Dreyer, A. 1936. Boustowwe vir die Nederduitse Gereformeerde Kerke in Suid-Afrika Deel 1111804 - 18036. Uitgegee deur die Jaarboekkommissie van die Raad van die Nederduits-Gereformeerde Kerke in Suid-Afrika 1936. p 357-358.

13 Kleynhans,E.P.J.,1973. Die kerkregtelike Ontwikkeling van die Nederduitse Gereformeerde Kerk in Suid-Afrika 1795-1962, 'n Kerkhistories-Kerkregtelike Studie. Proefskrif goedgekeur vir die graag Doktor in die teologie aan die Universiteit van Stellenbosch met prof.dr. T.N. Hanekom as promotor, November 1973, p 80.

14 Agenda van die Eerste Vergadering van die hoogeerwaarde Sinode van die Nederduitse Gereformeerde Kerk van Suid-Afrika gehou in Kaapstad op 11 Oktober 1962 en volgende dae. p 5-13 
the first ever Church Order for the whole Dutch Reformed Church ${ }^{15}$ was approved. Not a single word about marriage, the role of the church in the solemnization of marriages, where it had to be solemnized and what the role of ministers of religion are, is mentioned in the Church Order. In the Book of Liturgical Formulas of the Dutch Reformed Church also published in 1962 there is a Formula for the solemnization of marriages in which it is stated that marriage was instituted by God. The minister of religion who conducts the marriage is at the same time also a state official registered to officiate on behalf of the state at the solemnization of marriages and to declare when a couple is legally married. ${ }^{16}$ In the Liturgical Handbook of 1988, the role of the minister as a State official is even more clearly stated when he/she pronounces "I hereby declare that $\mathrm{AB}$ and $\mathrm{CD}$ are legally married. Give each other the rings as a symbol of your love and unity as man and wife." ${ }^{17}$ Before the same General Synod of 1962 there also served a report on divorce and remarriage. In the light of this report the Church laid down certain guidelines like: the authorities are servants of God and are bound by the ordinances of God, also those for marriage. They are therefore compelled to take the ordinances of God into account as much as possible in any legislation they make. ${ }^{18}$ In 1962 the Church also rejected malicious desertion as ground for divorce and claimed the right for its ministers to refuse to solemnize a marriage of divorcees if it goes against their conscience. ${ }^{19}$

In the meantime between 1962 and 1996 a lot of further changes were made in marriage legislation in South Africa. Already in 1953 a first dent was made in the husband's marital power in that sale of a woman's immovable property by her husband were no longer allowed. Women were also allowed control over their own earnings and to open bank accounts unassisted; 1970: the marriage age for girls decreased to 15 years and the requirement for bans and marriage licences were

15 Kerkorde van die Ned. Geref. Kerk van SA. In:Handelinge van die Eerste Vergadering van die Algemene Sinode van die Nederduitse Gereformeerde Kerk. Gehou in Kaapstad op Donderdag, 11Oktober en volgende dae. 1962, p 38-51.

16 Formulierboek van die Nederduitse Gereformeerde Kerk van Suid-Afrika 1962. NG Kerk Uitgewers, Kaapstad, Pretoria. p 52-60.

17 Handboek vir die Erediens van die Nederduitse Gereformeerde Kerk. NG KerkUItgewers, 1988. P106

18 Handelinge van die Eerste Vergadering van die Algemene Sinode van die Nederduitse Gereformeerde Kerk gehou in Kaapstad op Donderdag 11 Oktober 1962 en volgende dae. p. 100 en 101

19 Handelinge van die Eerste Vergadering van die Algemene Sinode van die Nederduitse Gereformeerde Kerk gehou in Kaapstad op Donderdag 11 Oktober 1962 en volgende dae. p.101. 
abolished; 1979: the main ground for divorce changed from "guilt" to "irretrievable breakdown"; 1984: The husbands marital power over his wife and joint estate was abolished and replaced by joint administration, the accrual system for marriages out of communion of property was also introduced. All of these new laws did not apply to black people. 1985: The Mixed Marriages Act was scrapped, which meant that interracial marriages were legal again; 1988: the law reforms of 1984 are extended to "black civil marriages; 1992: the Domicile Act allows married women to acquire their own legal domicile, previously she automatically acquired the domicile of her husband; 1993: the husband's legal status as "head of the household" is abolished; 1994: the husband's status as sole guardian of a married couple's children is removed - husband and wife are both guardians. ${ }^{20}$

In 1996 a new Constitution for South Africa was accepted. ${ }^{21}$ Apart from affecting every citizen of South Africa the Constitution also brought about significant changes and new challenges for churches and theology in South Africa. Chapter 2 of the Constitution contains a Bill of Rights with stipulations on equality and the equal protection and benefit of the law, ${ }^{22}$ the prohibition of unfair discrimination on grounds such as race, gender, sex, pregnancy, marital status, ethnic or social origin, colour, sexual orientation, age, disability, religion, conscience, belief, culture, language and birth. ${ }^{23}$ The Bill of Rights also protects rights such as human dignity, ${ }^{24}$ the right to life, ${ }^{25}$ freedom and security of the person, ${ }^{26}$ the right not to be subjected to slavery, servitude and forced labour, ${ }^{27}$ the right to privacy, ${ }^{28}$ the right to freedom of expression, ${ }^{29}$ assembly demonstration, picket and petition, ${ }^{30}$ and freedom of

20 Mercer, Susan, 2012. A brief history of marriage in South Africa. http://wealth coaching. co.za/wp/financial-education-2/aa-brief-historyof-marriage-in-s, accessed on 26/10/2014.

21 The Constitution of the Republic of South Africa. Act 108 of 1996.

22 The Constitution of the Republic of South Africa. Act 108 of 1996, article 9(1).

23 The Constitution of the Republic of South Africa. Act 108 of 1996, article 9(3).

24 The Constitution of the Republic of South Africa. Act 108 of 1996, article 10.

25 The Constitution of the Republic of South Africa. Act 108 of 1996, article 11.

26 The Constitution of the Republic of South Africa. Act 108 of 1996, article 12

27 The Constitution of the Republic of South Africa. Act 108 of 1996, article 13.

28 The Constitution of the Republic of South Africa. Act 108 of 1996, article 14.

29 The Constitution of the Republic of South Africa. Act 108 of 1996, article 16

30 The Constitution of the Republic of South Africa. Act 108 of 1996, article 17. 
association. ${ }^{31}$ Article 31 determines the rights of cultural, religious and linguistic communities in South Africa. ${ }^{32}$

Very important for religions in South Africa is article 15 of the Constitution. The first section of article 15 states "Everyone has the right to freedom of conscience, religion, thought, belief and opinion" ${ }^{33}$ Section 15(2) is about religion at state and state aided institutions and the conditions, which apply. ${ }^{34}$ Section 3 of article 15 allows for the recognition of marriages concluded under any tradition, or a system of religious, personal or family law, or systems of personal and family law under any tradition, or adhered to by persons professing a particular religion. ${ }^{35}$

Freedom of religion entail that religions in South Africa have the right to institutional freedom which means that every religious institution like a church has the right "(a) to determine its own confessions, doctrines and ordinances, (b) to decide for itself in all matters regarding its doctrines and ordinances, and (c) in accordance with the principles of tolerance, fairness, openness and accountability to regulate its own internal affairs."36

It is time that all religions in South Africa, and especially the Dutch Reformed Church, in the light of what the Constitution allows in article 15, take up the challenge and develop their own theology of marriage in accordance with their faith identity and not just uncritically accept what the state determines in the marriage act and other acts relating to intimate relationships between people.

Both the state and the church/religions have a real stake in the marriage as an institution. The state for the sake of an orderly society and the churches/religions because of their faith convictions and for the churches their obligation to comply with the demands of the Word of God regarding marriage itself and also to be witnesses of Jesus Christ and His kingdom. As can be seen from the foregoing history there was nearly always a tussle between the state and the church about who of them had the final say about marriage. In times of Caesero-Papal relationship between church and state it was the state that had a very important say although the state often allowed the church to have its convictions expressed in and through the marriage laws of the state. In a Caesero-Papal relationship between church and

31 The Constitution of the Republic of South Africa. Act 108 of 1996, article 18.

32 The Constitution of the Republic of South Africa. Act 108 of 1996, article 31.

33 The Constitution of the Republic of South Africa. Act 108 of 1996, article 15(1)

34 The Constitution of the Republic of South Africa. Act 108 of 1996, article 15(2)

35 The Constitution of the Republic of South Africa. Act 108 of 1996, article 15(3)(a).

36 The South African Charter of Religious Rights and Freedoms, art 9.1, www.crrf.org 
state it was also often the state recognising only one religion. In most cases this religion was the Christian religion. The Caesero-Papal relationship also brought about that Christianity was bound by the policies of the state and in a sense had to give a Christian legitimization to the policies of the state. Being a Christian and being a citizen became the same thing. In South Africa and in the Netherlands it became "being a citizen and being a reformed Christian" is the same thing. This was definitely not always good for the church. It often resulted in the Church and theology not developing a sound theology on marriage.

The new Constitutional dispensation in South Africa brought about significant changes and challenges not only for Churches but also for religions in the country with regard to the way they see marriage and how they are seen by the state with regard to marriage.

There is no longer a situation of a privileged church or religion in South Africa. Al religions be it Jewish, Christian, Muslim, Hindu, Ba'ai, African Independent Churches or the African Traditional Religion or whatever are equal before the Constitution and the laws of the land. Also all religions now have the opportunity to develop their own views and rules on the marriage of their members. This brings about a great responsibility for the religions and churches in South Africa to develop a spiritual viewpoint and theology on marriage that must give expression to their deepest faith convictions. The Constitution gives them this right in article 15(3).

If religions fail to express their faith convictions in their theology or system of thought and their internal laws it will mean that they and their members will automatically fall under the laws of the state to which they will be compelled to comply with. 